\title{
Topical Interferon alfa-2b for ocular surface squamous neoplasia in one case of patient with xeroderma pigmentosum
}

\author{
Uso tópico do inteferon alfa-2b para neoplasia \\ escamosa da superficie ocular em um caso de \\ paciente com xeroderma pigmentoso
}

Nayara Queiroz Cardoso Pinto ${ }^{1}$, Jhonatan de Paula Araujo Ferreira', Gustavo Jose Arruda Mendes Carneiro1, Jailton Vieira Silva ${ }^{1}$, Luanna Biana Costa Bezerra², Natália Ponte Nogueira ${ }^{3}$

\begin{abstract}
Report of a case of xeroderma pigmentosum with squamous cell carcinoma of bilateral conjunctiva that showed a significant regression in tumor size with the use of interferon alfa-2b topic. Case report: Female patient with Xeroderma pigmentosum in an advanced stage, with no healthy skin, having been subjected to about 60 excisions of malignant skin lesions. The patient appeared with conjunctival tumors in both eyes, corresponding to squamous cell carcinoma of the conjunctiva. Due to surgical difficulties, high relapse rate and high probability of symblepharon formation, therapy was started with interferon alpha 2beta 1,000,000 topic units, obtaining good results with a significant decrease in lesion size and resolution of symptoms. Conclusion: Topical use of alpha-interferon in 2 beta squamous neoplasia of the conjunctiva proved to be a good therapeutic option for high surgical risk and situations of postoperative complications.

Keywords: Xeroderma pigmentosum; Nevus, halo; Skin abnormalities; Skin neoplasms; Skin pigmentation; Eye neoplasms; Eye manifestations; Case reports
\end{abstract}

\section{RESUMO}

Relato de um caso clínico de Xeroderma Pigmentoso com carcinoma espinocelular de conjuntiva bilateral que apresentou regressão importante das dimensões tumorais com o uso de Interferon alfa-2b tópico. Relato de caso: Paciente feminina com Xeroderma Pigmentoso em estágio avançado, com ausência de pele sadia, tendo sido submetida a cerca de 60 exéreses de lesões de pele malignas. A paciente compareceu com tumoração conjuntival em ambos os olhos, correspondendo a carcinoma espinocelular de conjuntiva e neoplasia intraepitelial de conjuntiva em olho esquerdo. Devido as dificuldades cirúrgicas, alta taxa de recidiva e elevada probabilidade de formação de simbléfaro foi-se iniciado terapêutica com Interferon alfa-2beta 1.000.000 unidades tópico, obtendo-se bons resultados com importante regressão do tamanho da lesão e resolução dos sintomas. Conclusão: O uso tópico de interferon alfa-2beta em neoplasia escamosa de conjuntiva, mostrou-se uma boa opção terapêutica em situações de elevado risco cirúrgico e de complicações pós operatórias.

Descritores: Xeroderma pigmentoso; Nevus com halo; Anormalidades da pele; Neoplasias da pele; Pigmentação da pele; Neoplasias oculares; Manifestações oculares; Relato de casos

\footnotetext{
${ }^{1}$ Hospital Universitário Walter Canídeo, Fortaleza, CE, Brazil.

${ }^{2}$ Hospital Geral de Fortaleza, Ceará, Fortaleza, CE, Brazil.

${ }^{3}$ Irmandade Santa Casa de Misericórdia de São Paulo, São Paulo, SP, Brazil.

Study carried out at the Ophthalmology Service, Hospital Universitário Walter Cantídio, Fortaleza, CE, Brazil.
}

The authors declare no conflicts of interests.

Received for publication 14/10/2016 - Accepted for publication 07/12/2016. 


\section{INTRODUCTION}

$\mathbf{X}$ eroderma Pigmentosum (XP) is an recessive autosomal disorder of DNA repair, of genetically heterogeneous etiology and variable expressivity, resulting in sharp sensitivity to ultraviolet radiation (UV). The genetic heterogeneity reflects molecular changes at gene level found in a set of genes encoding proteins involved in the repair pathway by nucleotide excision in cells in the replicative or quiescent state. There are eight altered genes described, with variable expressivity of the physical and clinical manifestations being the result of the interaction between genetic risk, genetic heterogeneity and environmental exposure. ${ }^{(1)}$

It can occur in all ethnic groups with prevalence of 1:1,000,000 in Europe and the US, and 1:22,000 in Japan. There is also a predominance in countries of North Africa and the Middle East where consanguinity becomes more common. In Brazil, so far, there are no statistics showing the frequency of this syndrome, although some case reports have been described. ${ }^{(1)}$

The clinical manifestations of XP include extreme sun sensitivity (blistering burns with only a few minutes of exposure) and pigmentation changes (hyperpigmentation and depigmentation), ocular changes, presenting a risk greater than 10,000 times of developing neoplasms in areas exposed to the sun like the skin, mucous membranes and eyes. In addition, approximately $20 \%$ to $30 \%$ of patients may develop progressive neurological disease, being clinically manifested as progressive ataxia and spasticity and cognitive deterioration. The clinical manifestations of XP depend on both the molecular abnormality and environmental damage suffered, and they can evolve differently even within the same family group. ${ }^{(2,3)}$

Ocular manifestations are an important component of XP. They were first described in the 19th century, and included xerosis and corneal opacification. Ocular involvement related to $\mathrm{XP}$ involves the areas that are exposed to UV radiation such as eyelid and ocular surface. Its main complaints are photophobia, conjunctivitis, ectropion, exposure keratitis, which may lead to opacification of the cornea or vascularization, pterygium, and neoplasia. ${ }^{(3)}$

The changes begin in early childhood. The skin of the eyelid may atrophy, and ectropion or entropion may occur. The bulbar conjunctiva can become thin, pigmented, and atrophic, with inflammatory lesions and, which can eventually become malignant. The cornea may present a time of early tear film breakdown, edema, exposure keratitis, vascularization, pterygium (with accelerated growth), epithelial neoplasms and corneal opacity. Opacification may result from changes in the epithelium/stroma, or may be secondary to endothelial decompensation as a result of damage due to chronic sun exposure. ${ }^{(4,5)}$

The ophthalmologic follow-up of these patients should be done since childhood, because the alterations derived from the disease begin after 1 to 2 years of onset of sun exposure. Early diagnosis and treatment is the most appropriate way of conducting cases, especially in the case of neoplasms where timely treatment may be essential. ${ }^{(6)}$

The objective of this report is to demonstrate favorable outcome of the use of Interferon Alpha-2b topic as a therapeutic option in case of a patient with xeroderma pigmentosum associated to bilateral conjunctival neoplasia of the squamous cell.

The report was based on regular appointments during the follow-up of the patient in the service of Ophthalmology and other specialties at Hospital Universitário Walter Cantídio. On each visit, we recorded: visual acuity with Snellen chart, slit-lamp biomicroscopy with photography and neoplastic lesion measurement in millimeters, applanation tonometry and funduscopy.

\section{Case Report}

Female patient, 25 years diagnosed with XP for 15 years, attends the ophthalmology service complaining of low visual acuity (LVA) in both eyes complaining of worsening during the last 2 years associated to tearing and eye pain. Refresh Advanced ${ }^{\circledR}$ was used 5 times a day in both eyes, and there was excision of conjunctival lesion in the left eye 7 years ago. She mentioned previous history of excision of about 60 skin lesions in the dermatology service.

The physical examination showed visual acuity (VA) in the right eye (RE) of 20/200 and in left eye (LE) of hand movement. In the biomicroscopy RE, we can observe the presence of inferior symblepharo, conjunctival hyperemia, peripheral vascularization of the cornea, and vascularized lesion in conjunctiva, elevated and of papillomatous aspect in lower nasal area. The LE presented conjunctival hyperemia, corneal edema and peripheral vascularization, presence of vascularized lesion in the conjunctiva, irregular, lobed, invading the corneal surface in the upper temporal region $(20 \times 15 \mathrm{~mm})$ (Figure 1). The patient's appearance was of advanced dermal disease with severe involvement of the upper lips, nose and eyelids in ectoscopy (Figure 2).

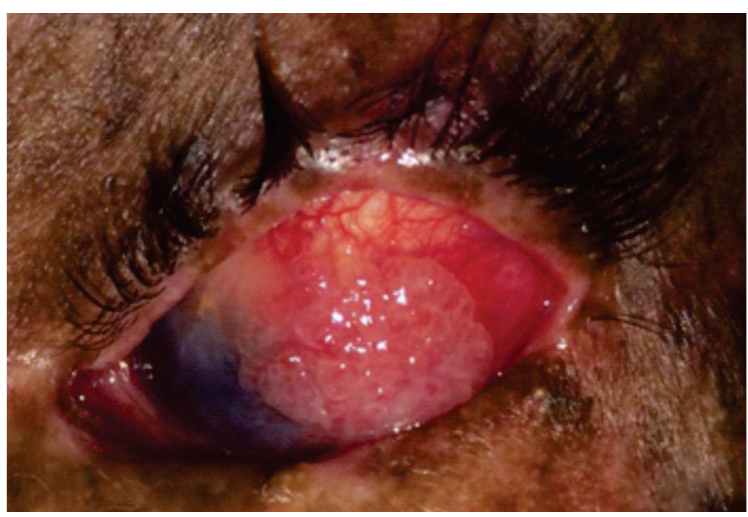

Figure 1. Primary lesion of the left eye

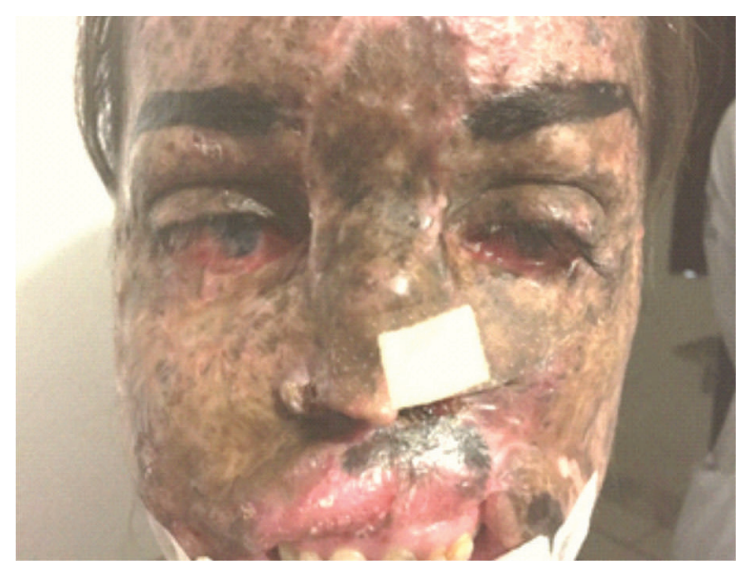

Figure 2. Aspect of the facial region of the patient with Xeroderma Pigmentosum 
The hypothesis for the case was bilateral and extensive conjunctival involvement by XP associated to possible ocular tumor lesions (squamous conjunctiva neoplasia), and with probable recurrence of the lesion in the LE, according to the American Joint Committee on Cancer Classification, with ocular lesion RE Tis and LE T2. The hypothesis was having an incisional biopsy of the lesions to identify the histological subtype (this type of biopsy does not allow us to define whether or not there is invasion of the lamina propria) and the performance of a Magnetic Nuclear Resonance (NMR) of the orbit to evaluate the extent of the lesion (Figures 3 and 4). The results of the biopsies were bilateral

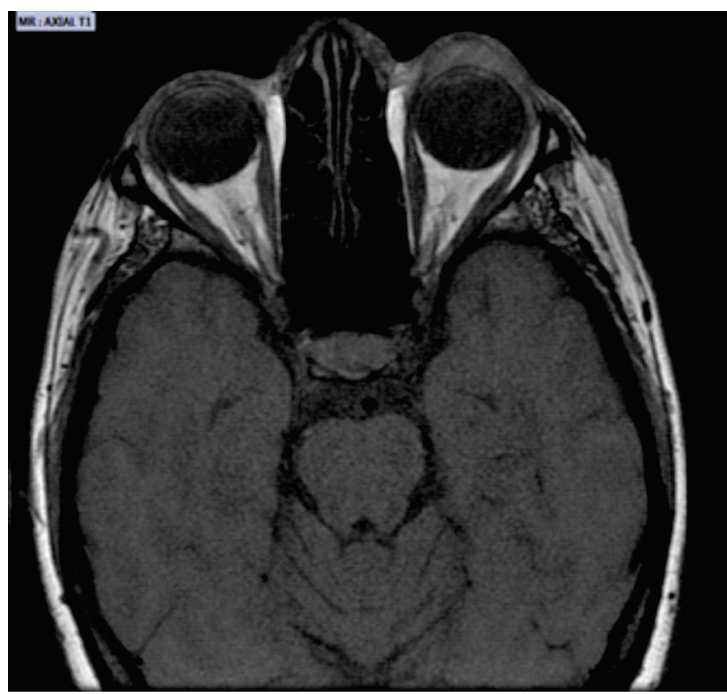

Figure 3. NMR showing hyperdense area in the anterior area of the left eye mode $\mathrm{T} 1$

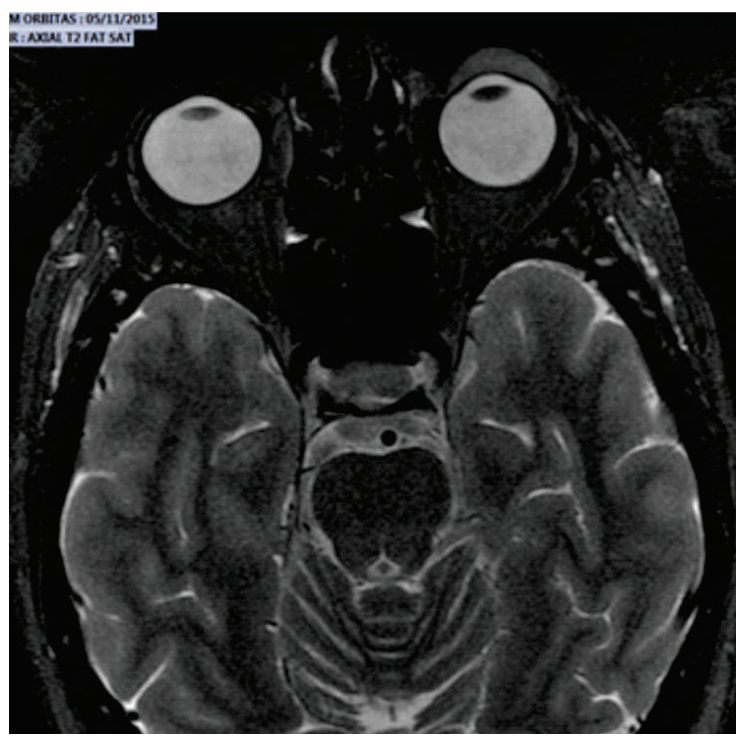

Figure 4. NMR showing hyperdense area in the anterior area of the left eye mode T2

squamous cell carcinoma "In Situ" (Figure 5) and High Grade Intraepithelial Neoplasia (Grade 3) in the left eye (Figure 6). NMR showed significant ocular lesion in the left eye, but without invasion of palpebral and orbital tissue.

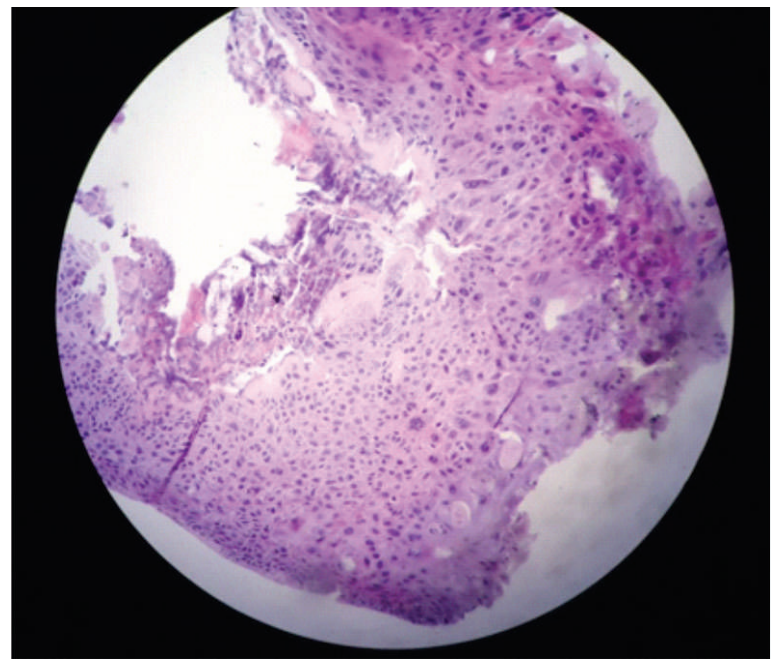

Figure 5. Histopathological aspect of right eye lesion demonstrating the appearance of squamous cell carcinoma "in situ"

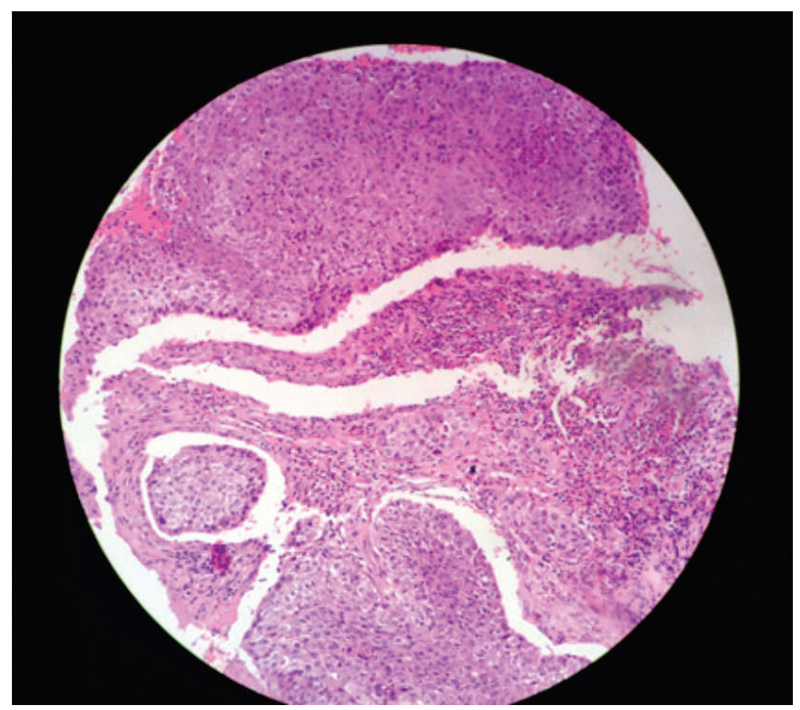

Figure 6. Histopathological aspect of the right eye lesion demonstrating epithelium with loss of maturation throughout its thickness associated to enlarged, hyperchromatic and irregularly contoured nuclei with aspect of "in situ" squamous cell carcinoma associated to High Grade Conjunctival Intraepithelial Neoplasia (Grade 3)

After diagnostic confirmation, topical therapy was initiated, using Interferon alfa- 2 beta $1,000,000 \mathrm{u} / \mathrm{ml}$ every $6 \mathrm{~h}$ in both eyes. After one month of therapy, we noticed a significant improvement in the lesion (Figure 7). The treatment was continued and reassessed 2 months afterwards (Figure 8). During this period, the patient reported visual and symptom improvement, with VA RE 20/100 and LE 20/400.

\section{Discussion}

Interferon alfa-2B is an immunomodulator that has several clinical indications. Its main reported actions are as antiviral, immunomodulator and antiproliferative complexes. Due to its various actions the medication has been used in several areas of medicine. Many articles discuss the use of this medication and its 


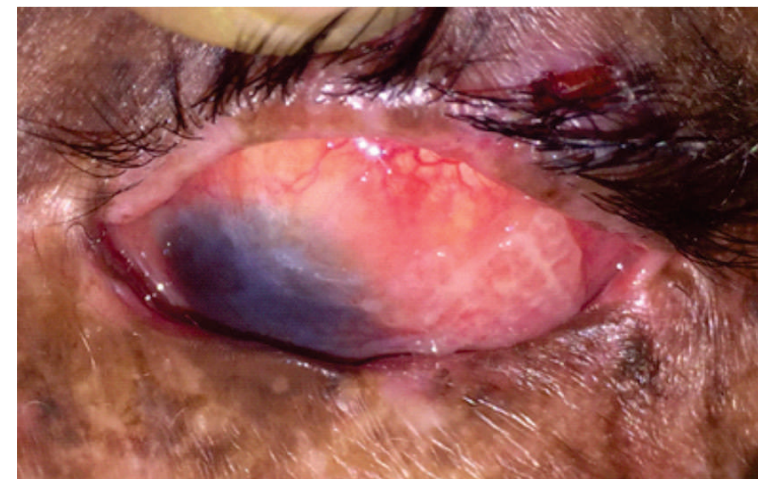

Figure 7. Left eye lesion after 30 days of use of Interferon eyedrops

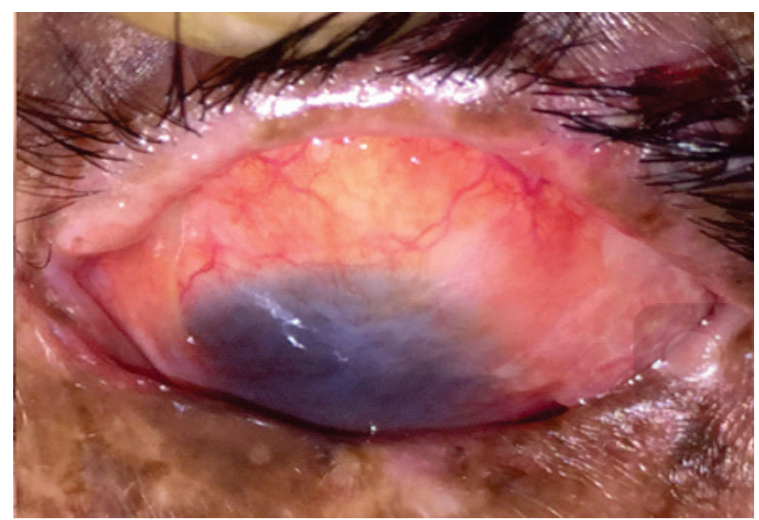

Figure 8. Left eye lesion after 2 months of use of Interferon eyedrops

effect on diseases such as dermal melanoma, polycythemia vera, hepatocellular carcinoma, and ocular diseases of the external and internal segments. ${ }^{(7-9)}$

Ocular treatments with Interferon alfa-2b have good therapeutic responses demonstrated in some studies. Nanji A.A. et al. reported a comparative study between the use of Interferon and surgical removal of lesions diagnosed as ocular surface squamous neoplasia (OSSN) where no major recurrence was evidenced with use of eyedrops. The 49 patients obtained total cure of the lesions in an average time of 2.3 months with a total average of 4 months of treatment. Kusumesh R. reported the effectiveness and safety of interferon as a single therapy in OSSN lesions, reaching total remission in $91.6 \%$ of patients treated and presenting low side effects, with a case of spontaneous tumor bleeding three weeks after the use of Interferon every 6 h. $^{(10-11)}$

Other reports also include good results in cases of primary melanoma acquired with atypia, conjunctival intraepithelial neoplasia, kaposi sarcoma, ocular melanoma (intravitreal use).(12-13)

In the current literature, there are still divergences regarding the best approach for neoplastic lesions of the ocular conjunctiva in these patients, but the most accepted treatment and best prognosis is the removal of all lesions with appearance and/ or diagnosis of malignancy with safety margin and therapy with cryotherapy on the margins of resection and/or intraoperative mitomycin $\mathrm{C}$. Their withdrawal cannot be conservative because of the high risk of local recurrences. In these reports they further describe the preferential use of Interferon alfa- $2 b$ in patients with extensive ocular disease in an attempt to preserve the eye in cases of non-invasion of the orbital content, in an attempt to avoid a more aggressive surgical procedure. ${ }^{(14)}$

In a study, 23 of the patients who had undergone some previous treatment for tumor lesion (excisional biopsy 9 [39\%], cryotherapy 2 [9\%], topical mitomycin C 1 [4\%], and topical Interferon alfa-2b $3[13 \%]$ ) presented recurrence and underwent a new therapy with Interferon alfa- $2 b$. The classification of tumors according to the AJCC classification (table 1) included in the studies the following categories: Tis (3 [13\%]), T3 (20, [87\%]), N0 (23 [100\%]), e M0 (23 [100\%]). The primary indication for the use of Interferon alfa-2b was extensive, unresectable ocular lesion in 15 tumors $(65 \%)$, with no surgical indication in 6 tumors $(26 \%)$, and low visual acuity in the contralateral eye in 2 tumors $(9 \%)$. The results of the study were total tumor resolution in 19 cases $(83 \%)$, and in $4(17 \%)$ there was a partial resolution of the lesion; one patient with XP in the study presented regression of $49 \%$ of the lesion size in 4 months, and the lesion remained stable for a period of 8 months. ${ }^{(15)}$

The surgical removal of the ocular lesions has a high chance of recurrence in this profile of patients, besides subjecting them to

\section{Table 1}

\section{. Classification of the "American Joint Committee on Cancer" for ocular surface squamous neoplasia (15)}

\begin{tabular}{ll}
\hline Clinic Category & Definition \\
\hline
\end{tabular}

\section{Primary Tumor}

TX Tumor cannot be assessed

T0 Tumor absent

Tis umor present as carcinoma in situ / Conjunctiva intraepithelial neoplasia

T1 umor present with greatest basal diameter $\leq 5 \mathrm{~mm}$

T2 Tumor present with greater basal diameter $\geq 5 \mathrm{~mm}$, without invasion of adjacent structures*

T3 Tumor invading adjacent structures

T4 Tumor invading the orbit with or without additional extension

T4a Tumor invades soft parts of the orbit without, bone invasion

T4b Tumor invading the bone

T4c Tumor invading underlying paranasal sinuses

T4d Tumor invading the brain

\section{Regional lymph node}

$\mathrm{Nx} \quad$ Nodules in regional lymph nodes cannot be assessed

N0 Nodules in regional lymph nodes without metastasis

N1 Nodules in regional lymph nodes with metastasis

\section{Distant metastasis}

$\begin{array}{ll}\text { M0 } & \text { Distant metastasis absent } \\ \text { M1 } & \text { Distant metastasis present }\end{array}$

*Adjacent structures include cornea, conjunctival fornice, palpebral conjunctiva, tarsal conjunctiva, intraocular compartments, lacrimal and canaliculi point, semilunar fold, anterior or posterior lamella of the eyelid, or margin of the eyelid. 
surgical stress by repeated interventions and having a great possibility of ocular sequelae such as symblepharon and other ocular surface alterations. Thus, the treatment with topical medication has shown to be a better option for the patient in question. Other studies corroborate the use of interferon as a good option for surgery, comparing the cost of the surgical treatment to the topical medication, showing similar results in both, with an additional visit to the office in the group of patients using Interferon alfa-2B. ${ }^{(16-18)}$

\section{RefERENCES}

1. Ryan SJ. Retina: basic science and inherited retinal disease. 4th ed. Philadelphia: Mosby; 2006. Vol. 1

2. Vilela MA, Colossi CG. Retinosquises. Rev Bras Oftalmol. 2011; 70(2):125-32.

3. Caye LM, Barbosa PH, et al. Uso da dorzolamida tópica em paciente portador de retinosquise juvenil ligada ao X. Rev Bras Oftalmol. 2010; 69(2):129-131.

4. Forsius H, Vainio-Mattila B, Eriksson A. X-linked hereditary retinoschisis. Br J Ophthalmol. 1962;46(11):678-81.

5. Sauer CG, Gehrig A, Warneke-Wittstock R, Marquardt A, Ewing CC, et al. Positional cloning of the gene associated withX-linked juvenile retinoschisis. Nat Genet. 1997;17(2):164-70.

6. Bastos AL, Freitas BP,Villas Boas O, Ramiro AC. Uso da dorzolamida tópica em pacientes com retinosquise juvenil ligada ao X. Arq Bras Oftalmol. 2008; 71(2): 286-90.

7. Kanski JJ, Bowling B. Clinical ophthalmology: a systematic approach. 7th ed. Edinburgh: Elsevier Saunders; 2011.

8. Nelson textbook of pediatrics. 19th ed. Philadelphia, PA; Elsevier/ Saunders; c2011. Disorders of the eye. Part 29.

9. Hofling-Lima AL, Moeller CT, Freitas D, Martins EN. Manual de condutas em Oftalmologia. São Paulo: Atheneu; 2008.

10. Audo I, ,lder GE, Moore A T. Inherited stationary disorders of the retina. In: Puech B, De Laey J-J, Holder GE, editors. Inherited chorioretinal dystrophies. A textbook and atlas. 2014.p. 77-98
11. Apushikin MA, Fishman GA. Use of dorzolamide for patients with X-linked retinoschisis. Retina. Retina. 2006;26(7):741-5. Erratum in: Retina. 2007;27(1):128.

12. Ober MD, Freund KB, Shah M,Ahmed S, Mahmoud TH, Aaberg TM Jr, Zacks DN, GaoH, Mukkamala K, Desai U, Packo KH, Yannuzzi LA. Stellate nonhereditary idiopathic foveomacular retinoschisis. Ophthalmology. 2014;121(7):1406-13.

13. Garip A, Schaumberger MM, Wolf A, Herold TR, Miller CV, Klingenstein A, et al. Evaluation of a short-term topical interferon $-2 \mathrm{~b}$ treatment for histologically proven melanoma and primary acquired melanosis with atypia. Orbit. 2016;35(1):29-34.

14. El Hamichi S, Messaoudi R, Belmalih M, Iferkhass S,Zerrouk R, Reda $\mathrm{K}$, Oubaaz A. Bilateral enucleation avoided by excision with mitomycin $\mathrm{C}$ for bilateral infiltrating conjunctival squamous cell carcinoma in a girl with xeroderma pigmentosum. J Fr Ophtalmol. 2015;38(7):e135-7.

15. Shah SU, Kaliki S, Kim HJ, Lally SE, Shields JA, Shields CL. Topical interferon alfa-2b for management of ocular surface squamous neoplasia in 23 cases: outcomes based on American Joint Committee on Cancer classification. Arch Ophthalmol. 2012 130(2):159-64.

16. Moon CS, Nanji AA, Galor A, McCollister KE, Karp CL. Surgical versus medical treatment of ocular surface squamous neoplasia a cost comparison. Ophthalmology. 2016; 123(3):497-504.

17. Joag MG, Sise A, Murillo JC, Sayed-Ahmed IO, Wong JR, Mercado C, Galor A, Karp CL. Topical 5-Fluorouracil 1\% as primary treatment for ocular surface squamous neoplasia. Presented Cornea Society; Fall Educational Symposium 2015. Ophthalmology. 2016123 (7):1442-8.

18. Krilis M,Tsang H, Coroneo M. Treatment of conjunctival and corneal epithelial neoplasia with retinoic acid and topical interferon alfa- $2 b$ : Long-term follow-up. Ophthalmology. 2012;119(10): 1969-73.

\section{Corresponding Author:}

Nayara Queiroz Cardoso Pinto

Rua Silva Paulet, 205 - Meireles, Ed. Studio 1 Fortaleza , CE, Brazil.

ZIP Code: 60.060-120

Phone No.: +55(84)99651-5533 